\title{
Preparedness and Approaches of Health Care Providers to Tackle the Transmission of COVID-19 Among South Gondar Zone Hospitals, Amhara, Ethiopia, 2020.
}

Minale Bezie Ambie ( $\nabla$ minaleemu1@gmail.com )

Debre Tabor University https://orcid.org/0000-0001-7013-0669

Habtamu Gebrehana Belay

Debre Tabor University

Dagne Addisu Sewyew

Debre Tabor University

\section{Research}

Keywords: Corona Virus, Health care provider, South Gondar

Posted Date: August 17th, 2020

DOI: https://doi.org/10.21203/rs.3.rs-57926/v1

License: (c) (1) This work is licensed under a Creative Commons Attribution 4.0 International License.

Read Full License 


\section{Abstract}

Objective: Preparedness and approaches of health care providers to tackle the transmission of covid-19 among South Gondar zonal hospitals 2020

Result: In this study a total of 422 health providers were interviewed from south Gondar zonal hospitals and overall response rate was $100 \%$. The mean range $35 \pm 6$ and minimum and maximum ranges of age were between 23 to 50 years and more than three fourth of the providers age range was $>35$ years. Regarding professions $203(48.1 \%), 112(26.5 \%)$ were nurses and midwifes respectively. The result over all was not good; people were not prepared preparedness of essential materials, equipments including psychological buildings of health providers in each hospital.

\section{Background}

Corona virus disease 2019 (COVID-19) is an emerging respiratory disease that is caused by a novel corona virus and was first detected in December 2019 in Wuhan, China. Disease is highly infectious, and main clinical symptoms include fever, dry cough, fatigue, myalgia, and dyspnea (1). Corona viruses distributed among humans, other mammals and have been implicated to cause respiratory, hepatic, gastrointestinal and neurological infections.(2).

The newly emerged novel corona virus from China has become a global health issue (3). Individuals with confirmed 2019-nCoVviruses have a clinical symptoms of fever, cough, and shortness of breath both lower and upper respiratory system $(4,5)$. In contrast to sever acute respiratory syndrome and middle east respiratory syndrome, recently happened beta corona viruses, 2019-nCoVhave mild clinical systems with low mortality rate (6). The time of incubation tends to be from two days to up to two weeks after acquiring the infection $(5,7)$.

SARS-CoV which causes SARS, has a unique pathogenesis because it causes both upper and lower respiratory tract infections(8). The initial result showed that SARS-CoV isolated from masked palm civets (9). The primary reservoir of SARS-CoV was putatively bat (10).

Study done at Saudi Arabia and adjacent countries MERS-CoV was derived from the nasal swabs of camel, and emerged in the Middle East with 2494 confirmed case and 858 death sequel (11). Its case fatality was approximately $36 \%$ over 26 countries, making MERS-CoV as one of the most devastating virus known to the human (12).

Route of transmitting among people directly via the respiratory droplets and secretion and indirectly through contaminated inanimate surfaces(13). Epidemiological investigations, the incubation period of the SARS-CoV-2 is between 1-14 days and virus has been found to be contagious in the asymptomatic patients (14).

\section{Materials And Methods}




\section{Study design, setting and area}

An Institutional-based cross-sectional study design was conducted from May to June 2020 in south Gondar Zonal hospitals, Amhara region, which is $666 \mathrm{~km}$ far from Addis Ababa, the capital of Ethiopia South Gondar zone is one of the zones in the Amhara regional with population of 2,485552. There are 6 primary Hospitals and 1400 health professionals

\section{Population}

\section{Source population}

All health care providers

\section{Study population}

All health care providers who were working in South Gondar public hospitals during the study period

\section{Sample population}

Selected health care providers

\section{Inclusion and exclusion criteria}

\section{Inclusion criteria}

All health professional

\section{Sample size determination}

The sample size have been calculated using a single population proportion formula as follows with $95 \%$ confidence level, and marginal of error $5 \%, 10 \%$ non-response rate; final sample size for this study was 422

\section{Sampling technique and procedure}

Respondents were allocated proportionally based on the number of the health workers. Study participants who fulfill the inclusion criteria were selected by systematic random sampling every two interval.

\section{Data collection tools and procedures}

Data was collected through a self-administered questionnaire and observation for the practice of standard precaution in fighting against COVID-19 pandemic. Study instrument was adapt from risk communication \& community Engagement action plan guidance of WHO COVID-19 preparedness \& response and related literatures $(17,18)$.Questionnaire was divided into 4 parts, demographic information, practice of standard precaution, mental preparedness of respondents evaluated with 
strongly agrees, agree, disagree and strongly disagree response and finally we compute to agree and disagree

\section{Data Quality Assurance}

The data collection tools were pretested three days prior to the actual data collection time with $5 \%$ of sample size of 21 health care providers at Bahirder hospital and necessary adjustment was made.

\section{Data analysis}

Data was entered and analyzed using SPSS 23 statistical software. Descriptive analyses run first with proportion and summary statistics to describe the study population in relation to relevant variables by considering statistical assumptions.

\section{Variables}

\section{Dependent Variables}

Covid-19 preparedness among healthcare providers

\section{Independent Variables}

Socio demographic indicator variables like

- Age,Sex

- Types of profession

- Educational Status

- Work experience

- Marital status

- Department

\section{Operational definition}

Self-satisfaction: participants were classified as a being satisfied of tools assessment to prevent corona virus disease pandemic, among 7 questionnaires, if a response rate was scored $>4$ questions put as satisfactory if $<4$ unsatisfactory

Social status related: participants were classified being as a agree and disagree on the perceptions of prevent transmit ion and treatment of corona virus disease from person to person

Place of work related questions: Among 8 questions, respondents were scored $>4=$ good and $<4$ poor Infection prevention related: participants were assessed preparedness of tools including PPE as a methods of infection prevention among 5 questions, scored $>3=$ good and scored $<3$ poor 


\section{Results}

\section{Socio demographic characteristics of health providers}

In this study a total of 422 health providers were interviewed from south Gonder zonal hospitals and overall response rate was $100 \%$. The median (+IQ range) age of health provider was 40 Std. deviation $6 \pm 4$ and minimum and maximum ranges of participants were 23 to 50 years and more than three fourth of the providers age range was $>35$ years around $255(60.4)$. Among the total respondents $341(80.8 \%)$, $81(19.2 \%)$ were males and females respectively. Regarding on marital status $336(79.6 \%)$ of the study subjects were married and $203(48.1 \%), 112(26.5 \%)$ of professions were nurses and midwifes respectively and then less than $(7.8 \%)$ were other departments like anesthesia, Laboratory and pharmacy. Majority of respondents $114(27 \%), 95(22.5 \%)$ had five and four years of work experience respectively. Among the total respondents, $(63.9 \%),(40.7 \%)$ were in progress and not availed in their infection prevention materials and personal protective equipments with less than (7.9\%) of completed prior preparedness of materials and PPE (Table 1).

\section{Table 1.Sociodemographic characteristics of health providers}




\begin{tabular}{|c|c|c|c|}
\hline Variables & Category & Frequency $(\mathrm{N}=422)$ & Percent \\
\hline \multirow[t]{4}{*}{ Providers age } & $<20$ & 0 & 0 \\
\hline & $20-35$ & 167 & 39.6 \\
\hline & $>35$ & 255 & 60.4 \\
\hline & Total & 422 & 100.00 \\
\hline \multirow[t]{2}{*}{ Marital status } & Married & 336 & 79.6 \\
\hline & Single & 86 & 20.4 \\
\hline \multirow[t]{2}{*}{ Religion } & Orthodox & 336 & 79.6 \\
\hline & Muslim & 86 & 20.4 \\
\hline \multirow[t]{8}{*}{ Professions } & Physicians & 15 & 3.6 \\
\hline & Nurses & 203 & 48.1 \\
\hline & Midwives & 112 & 26.5 \\
\hline & Pharmacist & 31 & 7.3 \\
\hline & Laboratory technologist & 28 & 6.6 \\
\hline & $\begin{array}{l}\text { Others(mental } \mathrm{H} \text {, anesthesia and } \\
\text { optometrist) }\end{array}$ & & \\
\hline & Total & 33 & 7.8 \\
\hline & & 422 & 100.00 \\
\hline \multirow[t]{5}{*}{ Year of experience } & $1-4$ & 117 & 27.7 \\
\hline & $5-10$ & 215 & 50.9 \\
\hline & $11-15$ & 55 & 13 \\
\hline & $16-20$ & 35 & 8.3 \\
\hline & Total & 422 & 100.00 \\
\hline \multirow{5}{*}{$\begin{array}{l}\text { Educational Level of } \\
\text { respondents }\end{array}$} & Diploma & 123 & 29.2 \\
\hline & Degree & 203 & 48.1 \\
\hline & Master & 41 & 9.7 \\
\hline & Specialists & 55 & 13 \\
\hline & Total & 422 & 100 \\
\hline
\end{tabular}

Practice assessment on standard precaution against COVID -19 
Covid-19 is new and contagious disease in the world that is why Health providers in each hospital have practicing the following general precautions for prevention and treatment of infectious respiratory diseases of covid-19 were taken to help prevent people. questions, were prepared and asked about using appropriately personal protective equipments by using never, sometimes, seldom and often questions, we can see that perceptions of using PPE and disinfections of materials before and after procedure have significant gaps between the amount of information available about covid-19 and adaptation of wearing personnel protective equipments and hand washing practice using soap and water were poor (Table:2)

Table: 2 Practice assessments on standard precaution against COVID -19 


\begin{tabular}{|c|c|c|c|}
\hline Variables & category & Frequency $(\mathrm{N}=422$ & Percent \\
\hline \multirow{5}{*}{$\begin{array}{l}\text { Wear appropriate medical } \\
\text { mask at all time }\end{array}$} & Never & 228 & 54 \\
\hline & Seldom & 36 & 8.5 \\
\hline & Sometimes & 158 & 73.4 \\
\hline & Often & No & No \\
\hline & Very Often & No & No \\
\hline \multirow{6}{*}{$\begin{array}{l}\text { Put on protective eye glass } \\
\text { always during procedure }\end{array}$} & Never & 108 & 25.6 \\
\hline & Seldom & 86 & 20.4 \\
\hline & Sometimes & 228 & 54 \\
\hline & Often & No & No \\
\hline & Very often & No & No \\
\hline & Total & 422 & 100.00 \\
\hline \multirow{3}{*}{$\begin{array}{l}\text { All body fluid and aerosol } \\
\text { droplet considered as } \\
\text { biohazards }\end{array}$} & Often & 336 & 79.6 \\
\hline & Very often & 86 & 20.4 \\
\hline & Total & 422 & 100.00 \\
\hline \multirow{3}{*}{$\begin{array}{l}\text { Wash hands with soaps and } \\
\text { water for } 20 \text { " before and } \\
\text { after procedure }\end{array}$} & Sometimes & 194 & 46 \\
\hline & Often & 228 & 54 \\
\hline & Total & 422 & 100.00 \\
\hline \multirow{4}{*}{$\begin{array}{l}\text { Put-on gown/plastic apron } \\
\text { when you do every procedure } \\
\text { and gloves }\end{array}$} & Seldom & 72 & 17.1 \\
\hline & Often & 264 & 62.6 \\
\hline & Very often & 86 & 20.4 \\
\hline & Total & 422 & 100.00 \\
\hline \multirow{3}{*}{$\begin{array}{l}\text { Instrument processing and } \\
\text { waste management }\end{array}$} & Sometimes & 264 & 62.6 \\
\hline & Often & 158 & 37.4 \\
\hline & Total & 422 & 100.00 \\
\hline \multirow{3}{*}{$\begin{array}{l}\text { Keep physical distancing of } \\
2 \text { arms lengths except } \\
\text { physical examination } \\
\text { especial cases }\end{array}$} & Seldom & 36 & 8.5 \\
\hline & Sometimes & 72 & 17.1 \\
\hline & Often & 314 & 74.4 \\
\hline
\end{tabular}




\begin{tabular}{|c|c|c|c|}
\hline & Total & 422 & 100.00 \\
\hline \multirow{4}{*}{$\begin{array}{l}\text { Refrain from touching their } \\
\text { eye, mouth and nose } \\
\text { potentially contaminated } \\
\text { gloved or ungloved hands }\end{array}$} & Sometimes & 72 & 17.1 \\
\hline & Often & 122 & 28.9 \\
\hline & Very often & 228 & 54 \\
\hline & Total & 422 & 100.00 \\
\hline
\end{tabular}

\section{Preparedness of tools and approaching methods}

\section{Self satisfactory towards perception of COVID-19}

Among the 7 self satisfaction questions of perceptions to give service for covid-19 pandemic disease, Majority of respondents were satisfactory, which was answered $>4$ questions agree $<4$ were disagree that was unsatisfactory $214(50.7 \%), 208(49.3 \%)$ respectively

\section{Social status towards preventive measures of COVID-19}

In our study, participants believed that in all 6 questions regarding social related assessments 242 (57.3\%), $180(42.7 \%)$ of participants were agreed and disagreed respectively to limit their social activities, transmit to their family, not disclosing to their families if covid-19 positive because of avoid them and agree to live alone if positive COVID-19.

\section{Work place related questions towards prevention/treatment of covid-19}

Among the eight questions $>4$ and $<4$ questions having assigned final agreed and disagree. Therefore 255(60.4\%), 167(39.6\%) respectively were agree and disagree of prevention COVID -19 disease since increases their work load, institution does not support if COVID positive, perceptions if absence of work place can reduce transmit ion and even if they can change current job from health to para health.

\section{Infection prevention measures of covid-19}

The status of the general health providers in each hospital towards preparedness of infection prevention equipments, were asked 5 questions. Answering and scoring system was good and poor if answered $>3$ and $<3$ among 5 questions. (Below pie chart 1)

\section{Availability of infection prevention materials and personal protective equipments}

Study was not completely prepared materials and PPE beyond activities that involve close contact with a suspected or confirmed case of COVID-19, and not only COVID -19 but also for regular activities in each hospitals were in progressing of availability infection prevention materials and ensure the health care providers were not applying standard precautions for all patients. All hospitals were not ready to prepare essential equipments and team of health care workers were not received training in order to prevent standard, contact, droplets, and airborne precautions.(Table:3) 
Table3: Assessment of tool preparedness in South Gondar zone public hospitals

\begin{tabular}{|c|c|c|c|}
\hline Variables & Category & Frequency & Percent \\
\hline \multirow{5}{*}{$\begin{array}{l}\text { Health care workers (HCW), patients, and visitors are aware of } \\
\text { respiratory and hand hygiene. Provide verbal instructions, } \\
\text { informational posters, cards, etc. }\end{array}$} & No & 195 & 46.2 \\
\hline & \multirow{2}{*}{$\begin{array}{l}\text { In } \\
\text { progress }\end{array}$} & 186 & 44.1 \\
\hline & & 41 & 9.7 \\
\hline & Complete & 422 & 100.00 \\
\hline & Total & & \\
\hline \multirow{5}{*}{$\begin{array}{l}\text { Ensure that } \mathrm{HCW} \text { are applying standard precautions for all } \\
\text { patients. }\end{array}$} & No & 189 & 44.8 \\
\hline & \multirow{2}{*}{$\begin{array}{l}\text { In } \\
\text { progress }\end{array}$} & 206 & 48.8 \\
\hline & & 27 & 6.4 \\
\hline & Complete & 422 & 10000 \\
\hline & Total & & \\
\hline \multirow{5}{*}{$\begin{array}{l}\text { Droplets and contact precautions are prepared for suspected or } \\
\text { confirmed COVID-19 cases }\end{array}$} & No & 186 & 44.1 \\
\hline & \multirow{2}{*}{$\begin{array}{l}\text { In } \\
\text { progress }\end{array}$} & 207 & 49.1 \\
\hline & & 29 & 6.9 \\
\hline & complete & 422 & 100.00 \\
\hline & Total & & \\
\hline \multirow{5}{*}{$\begin{array}{l}\text { Team of HCWs received training on standard, contact, droplets, } \\
\text { and airborne precautions }\end{array}$} & No & 73 & 17.3 \\
\hline & \multirow{2}{*}{$\begin{array}{l}\text { In } \\
\text { progress }\end{array}$} & 321 & 76.1 \\
\hline & & 28 & 6.6 \\
\hline & Complete & 422 & 100.00 \\
\hline & Total & & \\
\hline \multirow{5}{*}{$\begin{array}{l}\text { Available adequate personal protective equipment (PPE) (i.e., } \\
\text { medical/surgical masks, N95, gloves, gowns, eye protection) }\end{array}$} & No & 190 & 45 \\
\hline & \multirow{2}{*}{$\begin{array}{l}\text { In } \\
\text { progress }\end{array}$} & 219 & 51.9 \\
\hline & & 13 & 3.1 \\
\hline & comple & 422 & 100.00 \\
\hline & Total & & \\
\hline
\end{tabular}

\section{Discussion}


In our study area, this is the first study towards tackling COVID-19 by prior preparing things which are essential like personal equipments and other material to be ready in all hospitals. Indicating that most respondents found (50.7\%) were satisfactory on the preparedness assessment tool questions and (57.3\%) participants were agreed with their perceptions of socially approached methods (60.4\%).Strength of psychological buildings of individuals had huge gaps between.

Among the respondents, more than half $(54.3 \%)$ had poor response because of health providers were not have a got adequate information available on COVID-19 of infection prevention methods, particularly about the mode of transmission and appropriate use of personal protective equipments. About (56.8\%) of availability of infection prevention and personnel protective equipments were in progress, psychological buildings.

\section{Conclusion}

Over all result was not good; people were not prepared preparedness of essential materials, equipments including psychological buildings of health providers in each hospital.

\section{Declarations}

\section{Ethics approval and consent to participate}

Ethical approval was applied from Ethical Review Board of Debre Tabor University. An informed written consent was obtained from participants to fill the questionnaires. Privacy and confidentiality of information was kept by replacing all names with codes. Each study subject was informed about the objective of the study. A letter of cooperation was obtained from College of Health science for all Health facilities to participate in this study.

\section{Consent for publication}

Not applicable in this study

\section{Availability of data and materials}

Data sets in this study are available from the corresponding authors on reasonable request

\section{Competing interests:}

The authors declare that they have no competing interests

\section{Funding}

We are thanks to Debre Tabor University College of health science for their financial support. Although, beyond financial support, the funders did not have any role in the design of the study and analysis including writing the manuscript. 


\section{Authors' contributions}

MB participated in designing the study, gives training on data collection, supervising during data collection, analyzes the data and wrote over all research including manuscript. HG contributed in the designing of the data collection, analysis of the data, data processing, data collection and analysis the data. All authors read and approved the final manuscript. DA contributed in the designing of the data analysis

\section{Acknowledgements}

We would like to express our deepest gratitude and appreciation to Debre Tabor University, research and community services directorate for the unreserved and continuous service, especially for researchers and academicians. We were also acknowledged all data collectors and people who were participants in this study.

\section{Abbreviations}

SARS:Sever acute respiratory syndrome,MERS:Middle East respiratory syndrome,WHO:world health origination ,DGH:Debre Tabor general hospital,AOR:Adjusted odes ratio,COVID:Coronavirus19disease,PPE:personal protective equipment

\section{References}

1. Zhong B-L, Luo W, Li H-M, Zhang Q-Q, Liu X-G, Li W-T, et al. Knowledge, attitudes, and practices towards COVID-19 among Chinese residents during the rapid rise period of the COVID-19 outbreak: a quick online cross-sectional survey. Int J Biol Sci. 2020;16(10):1745-52.

2. Wei Ji, Wang W, Zhao X, Zai J, Li X. Cross-species transmission of the newly identified coronavirus 2019-nCoV. J Med Virol. 2020 92:433-440(DOI: 10.1002/jmv.25682).

3. Zhu N, Zhang D, Wang W, Li X, Yang B, Song J, et al. China Novel Coronavirus Investigating and Research Team. A novel coronavirus from patients with pneumonia in China, 2019. N Engl J Med. 2020;10.

4. Carlos WG, Dela Cruz CS, Cao B, Pasnick S, Jamil S. Novel Wuhan (2019-nCoV) Coronavirus. American Journal of Respiratory and Critical Care Medicine. 2020(ja).

5. Huang C, Wang Y, Li X, Ren L, Zhao J, Hu Y, et al. Clinical features of patients infected with 2019 novel coronavirus in Wuhan, China. The Lancet. 2020.

6. Chen Y, Liu Q, Guo D. Emerging coronaviruses: genome structure, replication, and pathogenesis. Journal of medical virology. 2020.

7. Chen N, Zhou M, Dong X, Qu J, Gong F, Han Y, et al. Epidemiological and clinical characteristics of 99 cases of 2019 novel coronavirus pneumonia in Wuhan, China: a descriptive study. The Lancet. 2020. 
8. Chen J. Pathogenicity and Transmissibility of 2019-nCoV-A Quick Overview and Comparison with Other Emerging Viruses. Microbes and infection. 2020.

9. Paraskevis D, Kostaki EG, Magiorkinis G, Panayiotakopoulos G, Sourvinos G, Tsiodras S. Full-genome evolutionary analysis of the novel corona virus (2019-nCoV) rejects the hypothesis of emergence as a result of a recent recombination event. Infection, Genetics and Evolution. 2020:104212.

10. Chan JF-W, Kok K-H, Zhu Z, Chu H, To KK-W, Yuan S, et al. Genomic characterization of the 2019 novel human-pathogenic coronavirus isolated from a patient with atypical pneumonia after visiting Wuhan. Emerging Microbes Infections. 2020;9(1):221-36.

11. Lu L, Liu Q, Zhu Y, Chan K-H, Qin L, Li Y, et al. Structure-based discovery of Middle East respiratory syndrome coronavirus fusion inhibitor. Nature communications. 2014;5(1):1-12.

12. Su S, Wong G, Shi W, Liu J, Lai AC, Zhou J, et al. Epidemiology, genetic recombination, and pathogenesis of coronaviruses. Trends in microbiology. 2016;24(6):490-502.

13. Thompson R. Pandemic potential of 2019-nCoV. Lancet Infect Dis. 2020;20(3):280.

14. Jin Y-H, Cai L, Cheng Z-S, Cheng H, Deng T, Fan Y-P, et al. A rapid advice guideline for the diagnosis and treatment of 2019 novel coronavirus (2019-nCoV) infected pneumonia (standard version). Military Medical Research. 2020;7(1):4.

15. Chan JF-W, Yuan S, Kok K-H, To KK-W, Chu H, Yang J, et al. A familial cluster of pneumonia associated with the 2019 novel coronavirus indicating person-to-person transmission: a study of a family cluster. The Lancet. 2020.

16. Xu C, Luo X, Yu C, Cao S-J. The 2019-nCoV epidemic control strategies and future challenges of building healthy smart cities.

17. Organization WH. COVID-19: operational guidance for maintaining essential health services during an outbreak: interim guidance, 25 March 2020. World Health Organization, 2020.

18. Zhong B-L, Luo W, Li H-M, Zhang Q-Q, Liu X-G, Li W-T, et al. Knowledge, attitudes, and practices towards COVID-19 among Chinese residents during the rapid rise period of the COVID-19 outbreak: a quick online cross-sectional survey. International Journal of Biological Sciences. 2020;16(10):1745. 